\title{
Tinjauan Literatur Pengolahan Air Limbah dengan Biomassa Granular Aerobik pada Mode Operasi Kontinu
}

\author{
${ }^{1)}$ Andik Yulianto; ${ }^{2)}$ Prayatni Soewondo; ${ }^{2)}$ Marisa Handayani; ${ }^{2)}$ Herto Dwi Arisyady \\ ${ }^{1)}$ Sekolah Pascasarjana Institut Teknologi Bandung \\ 2) Jurusan Teknik Lingkungan, Institut Teknologi Bandung \\ ${ }^{1)}$ Email: andik_y@yahoo.com
}

\begin{abstract}
Abstrak
Perubahan paradigma pengolahan air limbah yang menjadikan limbah sebagai sumberdaya membawa konsekuensi pada strategi pengolahan limbah yang harus dilakukan. Salah satu strategi adalah dengan menggunakan teknologi pengolahan air limbah menggunakan biomassa granular aerobik (Granular Aerobic Sludge, GAS) yang mempunyai kelebihan dalam beberapa hal dibandingkan dengan pengolahan air limbah dengan lumpur aktif konvensional. Penelitian yang dilakukan sebagaian besar menggunakan reaktor dalam mode operasi sequencing batch dan masih sedikit yang menggunakan mode operasi kontinu. Makalah ini mengkaji penggunaan reaktor kontinu dengan menggunakan GAS. Kajian dilakukan dengan penelusuran literatur. Hasil penelusuran literatur meunjukkan, mode operasi kontinu sudah dicoba sejak awal tahun 2000. Strategi untuk pembentukan GAS pada rektor kontinu yang dilakukan adalah dengan menambahkan inti presipitat dan memodifikasi reaktor konvensional. Apabila dibandingkan dengan penggunaan reaktor dengan mode operasi sequencing batch, maka mode operasi kontinu ini belum banyak dikembangkan, dan cenderung menghasilkan GAS dengan kualitas yang lebih rendah. Dengan demikian ruang untuk pengembangan reaktor untuk GAS pada mode operasi kontinu masih cukup luas.
\end{abstract}

Kata Kunci : biomassa granular aerobik, reaktor kontinu

\section{PENDAHULUAN}

Pemanfaatan teknologi pengolahan air limbah secara fungsi telah bergeser, dari hanya sekedar memenuhi baku mutu pengolahan menuju ke fungsi-fungsi pengambilan kembali sumberdaya (resource recovery), dalam bentuk penggunaan ulang dan daur ulang. Pemenuhan baku mutu kualitas olahan air limbah mengacu pada fungsi dasar dari pengolahan air limbah, yaitu untuk melindungi kesehatan manusia, terpenuhinya fungsi-fungsi estetika, dan perlindungan terhadap penurunan fungsi dan kualitas lingkungan. Sedangkan fungsi penggunaan ulang dan daur ulang mengacu pada pandangan dasar bahwa air limbah sebenarnya adalah sumber daya. Studi dari STOWA (Roeleveld, et al., 2010) menyebutkan bahwa paling tidak ada tiga sumber daya yang dapat diambil dari air limbah, yaitu air, nutrien dan energi. Konsep ini masih terus berkembang dan memerlukan kajian mendalam untuk aplikasinya terutama terkait dengan permasalahan integrasi dan kombinasi yang tepat (Mo \& Zhang, 2013).

Pengolahan air limbah di kawasan perkotaan dengan tujuan mendapatkan air yang dapat dapat digunakan kembali menghadapi permasalahan masih relatif tingginya kadar nutrien ( $\mathrm{N}$ dan $\mathrm{P}$ ) pada 
effluen (Oakley et al., 2010). Hal ini juga terjadi di Indonesia, misalnya hasil studi kinerja IPAL Komunal di Jogjakarta oleh Widodo, et al., (2009) menunjukkan masih relatif tingginya kadar nutrien ini pada effluen pengolahan air limbah komunal. Permasalahan lain yang dihadapi pada pengolahan air limbah di kawasan perkotaan Indonesia adalah masih mengandalkan pengolahan yang mudah untuk dioperasikan dan berbiaya rendah.

Ada beberapa strategi yang dapat dilakukan untuk memperbaiki kondisi ini antara lain dengan menerapkan teknologi pengolahan nutrien menggunakan pengolahan secara pra-anoksik, postanoksik dan pengolahan simultan nitrifikasi-denitrifikasi (Oakley et al, 2010). Salah satu metode simultan yang dapat digunakan adalah teknologi pengolahan dengan menggunakan biomassa granular aerobik (Granular Aerobic Sludge, GAS) untuk penyisihan nitrogen dan fosfor (Beun, et. al., 2001; Coma et. al, 2012; Coma et. al, 2010; Castro-Barros, 2013). Pada awalnya teknologi granular ini secara hanya dikenal pada pengolahan air limbah secara anaerobik, khususnya reaktor Upflow Anaerobic Sludge Blanket (UASB). Tetapi kemudian biomassa granular ini dapat terbentuk pada kondisi aerobik, tanpa perlu material lain sebagai inti (Morgenroth, et al, 1997). Berbagai referensi menyebutkan keunggulan teknologi ini terutama pada kemampuan pengendapan biomassa yang cepat, karena densitasnya yang besar, sehingga memperkecil kebutuhan lahan untuk pengendapan. Teknologi ini dianggap sebagai alternatif yang baik untuk Lumpur aktif (Bruin et. al., 2004). GAS juga memungkinkan untuk diterapkan pada skala komunal (Li et al, 2006; Chiavola, et al, 2010), meskipun untuk limbah domestik memerlukan waktu start-up yang lebih panjang (de Kreuk \& Loosdrecht, 2006; Loosdrecht, 2012). Kekurangan lain adalah pembentukan granulasi yang memerlukan waktu lama, dan kemungkinan mikroba yang tergranulasi terutama terbentuk dari bakteri Patogen (Ivanov \& Tay, 2006).

Teknologi pengolahan dengan menggunakan GAS secara umum banyak digunakan pada reaktor Sequencing Batch Reactor (SBR). Beberapa review terkait penggunaan teknologi ini antara lain dari Adav et. al, (2008), di Iaconi et. al., (2007), Nor Anuar et. al, (2006), dan desain reaktor GAS oleh Castro-Barros (2013). Dalam skala besar, aplikasi teknologi pada skala penuh juga menggunakan teknologi SBR (De Kreuk, 2006; Loosdrecht, 2011; Giesen, et al., 2013). Kondisi ini tentunya menimbulkan permasalahan bagaimana sampai sejauh ini riset yang telah dilakukan terkait dengan reaktor di luar SBR yang menggunakan GAS. Makalah ini secara khusus mengkaji perkembangan teknologi dengan menggunakan GAS dalam bentuk reaktor menerus (kontinyu). Pemilihan reaktor menerus selain secara operasional berbeda dengan kondisi operasional reaktor batch pada SBR, disebabkan juga secara operasional lebih praktis dibandingkan SBR. 
Jumlah publikasi menyangkut biomassa granular aerobik meningkat secara signifikan. De Kreuk (2006) mencatat, dari 1 jurnal di Tahun 1997, jumlah jurnal yang diterbitkan pada Tahun 2005 mencapai 60 buah dan terus bertambah sampai saat makalah ini ditulis. Hal ini menyebabkan perlunya pemetaan mengenai hal-hal yang telah dicapai di dalam aplikasi teknologi ini.

Metode penulisan makalah ini beradasarkan penelusuran literatur terutama berupa jurnal, thesis atau disertasi terkait dengan topik riset GAS terutama terkait dengan penggunaan reaktor. Penelusuran terutama dilakukan pada sumber-sumber di internet atau sumber-sumber lain yang dapat diakses penulis. Hal ini tentunya membawa konsekuensi adanya referensi yang tidak dapat dikaji akibat tidak dipublikasikan di internet. Hasil tinjauan literatur dibagi dalam beberapa sub deskripsi menyangkut GAS dan SBR, reaktor GAS non-SBR dan reaktor kontinu untuk pertumbuhan GAS.

\subsection{GAS pada SBR}

GAS dapat didefinisikan sebagai agregat yang berasal dari mikroorganisme yang tidak berkoagulasi apabila gaya geser hidrodinamik diturunkan dan secara signifikan mengendap lebih cepat apabila dibandingkan dengan flok lumpur aktif, mempunyai diameter dan metode pemanenan tertentu (Ni, 2013). GAS dianggap sebagai bentuk biofilm yang tumbuh tanpa adanya tambahan media luar (Castro-Barros, 2013). Pembentukan ini terjadi akibat adanya materi yang disebut EPS yang dikeluarkan oleh mikroorganisme. Materi ini merupakan susunan dari protein, polisakarida, asam humus, dan lemak yang meningkatkan adhesi sel (Adav, et. al, 2008).

Meskipun memiliki kemiripan, tetapi GAS mempunyai struktur yang berbeda dengan Flok Lumpur aktif. Perbedaan ini selain pada kondisi fisik (Minh, 2006), juga pada proses pembentukan dan konsorsium bakteri pembentuknya (Winkler, 2012). Winkler (2012) menyebutkan perbedaan struktur keduanya, yaitu pada GAS berbentuk kondisi yang lebih seragam antar lapisan, dimana secara konsentris dengan lapisan (dari luar ke dalam) kondisi yang terbentuk adalagh aerobik, anoksik, dan anerobik, yang hal ini tidak terbentuk pada flok lumpur aktif, meskipun mikroorganisme pembentunya relatif sama. Perbedaan ini ditunjukkan pada Gambar 1. Sehingga proses pada GAS memungkinkan terjadinya proses simultan, dimana selain degradasi substrat, dimungkinkan juga terjadi degradasi nutrien baik nitogen maupun phospat (de Kreuk, 2007). Kondisi ini ditunjukkan pada Gambar 2.

Reaktor SBR dan Sequencing Batch Airlift Reactor (SBAR) seringkali menjadi pilihan utama ddengan alasan seluruh proses (kontak dan pemisahan) terjadi di dalam satu reaktor, desain reaktor 
yang relatif sederhana, struktur GAS yang terbukti lebih baik (Beberapa penelitian menyebutkan mengenai faktor-faktor yang berpengaruh pada pembentukan GAS pada SBR. Ivanov \& Tay.
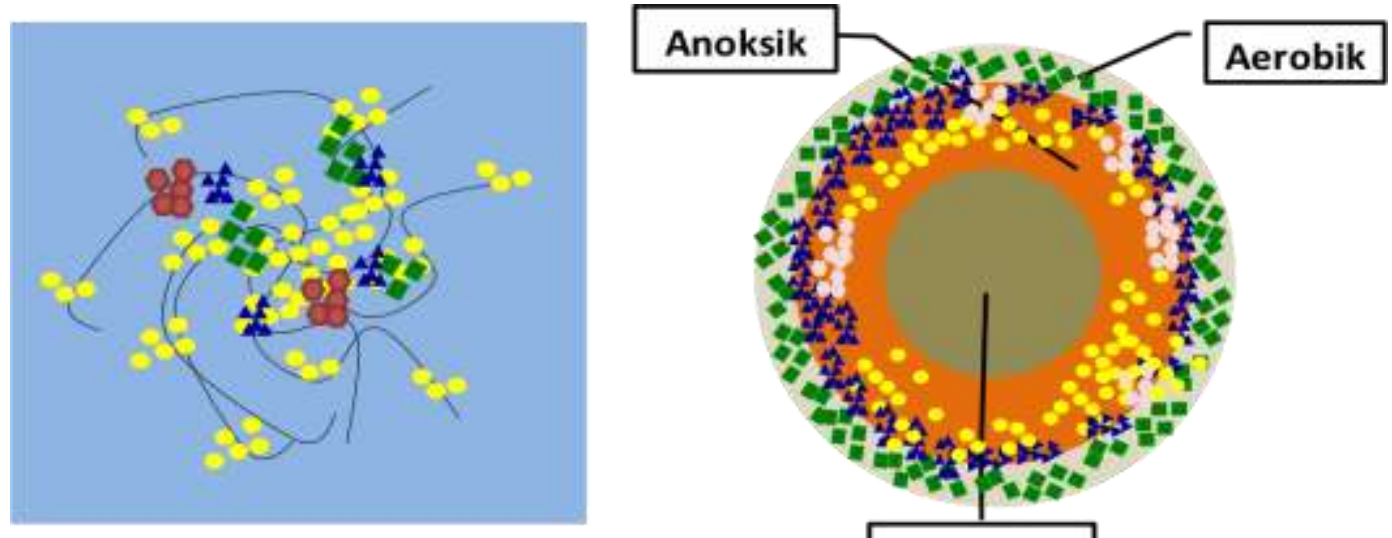

\section{PAO (Polyphosphate accumulating organisms) Nitrifikasi GAO (Glycogen-accumulating organisms) of Denitrifikasi}

Gambar 1. Perbedaan struktur flok lumpur aktif (a) dan GAS (b) (diadaptasi dari Winkler, 2012)

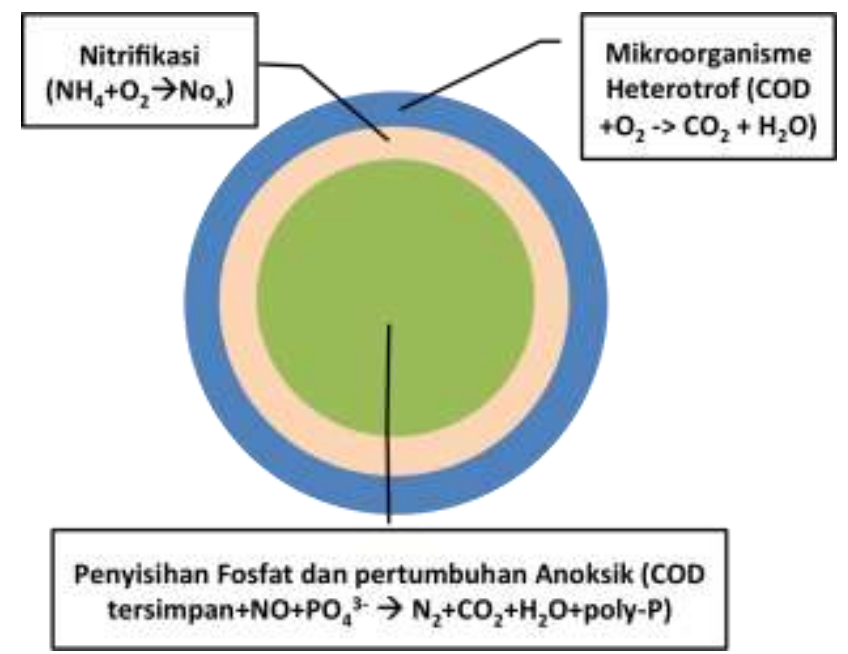

Gambar 2. Proses yang terjadi pada GAS (diadaptasi dari de Kreuk, 2007)

(2006), Liu (2006b), Yuan \& Gao (2010), dan Castro-Barros (2013), menyebutkan faktor tersebut antara lain adalah komposisi substrat, beban substrat (organic loading rate), Solid retention time, penambahan flokulan, penyesuaian $\mathrm{pH}$, penambahan suspended carrier, penambahan biogranular, aerasi yang optimal, dan efek mekanikal yang menyebabkan sel teragregat. Pada reaktor SBR, 
dalam waktu operasi yang panjang, dimungkinkan GAS kehilangan stabilitas (Adav, et al, 2008). Hal ini terjadi akibat granul pecah atau tumbuhnya filamen secara berlebih.

Faktor lain yang berpengaruh adalah hidrodinamika pada reaktor. Hidrodinamika ini dipengaruhi oleh gaya geser (shear force) yang dihasilkan dari proses aerasi dan dimensi reaktor dan distribusi kecepatan dalam aliran multifase (air, udara dan granular) pada reaktor SBR (Zima-Kulisiewicz, 2008). Untuk aerasi, paling tidak kecepatan udara harus lebih besar dari $1.2 \mathrm{~cm} . \mathrm{s}^{-1}$, untuk menstimulasi pembentukan polisakarida dan menaikkan kapasitas hidrofobiknya (Tay, et al, 2001; Moghadam, 2012). Sedangkan untuk dimensi reaktor, dipengaruhi oleh adalah rasio antara ketinggian $(\mathrm{H})$ terhadap diameter $(\mathrm{D})$, dengan rasio H/D yang besar menggunakan aliran upflow kan menghasilkan interaksi yang optimal antara aliran dan agregat mikrobial (Liu, 2006b).

Glukosa dan asetat adalah substrat yang paling sering digunakan di dalam percobaan di laboratorium (Bachtiar \& Handajani, 2013; Jang, et al, 2003). Beberapa variasi substrat pada aplikasi GAS dengan SBR antara lain limbah peternakan (Othman, et al., 2013), lindi sampah (Wei, et al, 2012), Tekstil (Pewarna sitetis) (Muda, et al, 2011), limbah pertanian (POME) (Abdullah, et. al, 2011), endocrine disrupter compounds dari limbah domestik (Balest, et. al., 2008), limbah Susu (Schwarzenbeck, et al, 2005).

Pengembangan model kinetika pada GAS dianggap mengikuti asumsi GAS sebagai model pertumbuhan tersuspensi atau model melekat (Cui \& Kim, 2013). Terkait dengan pertumbuhan biomassa granular beberapa model telah dibuat, antara lain model kinetika pertumbuhan granular aerobik (Liu, et al, 2005; Liu \& Tay, 2007) dan model matematika oleh (Ni, 2013).

\subsection{Reaktor dengan GAS non-SBR}

Secara ringkas, pengguaan reaktor yang memanfaatkan GAS sebagai biomassa ditunjukkan pada Gambar 3. 


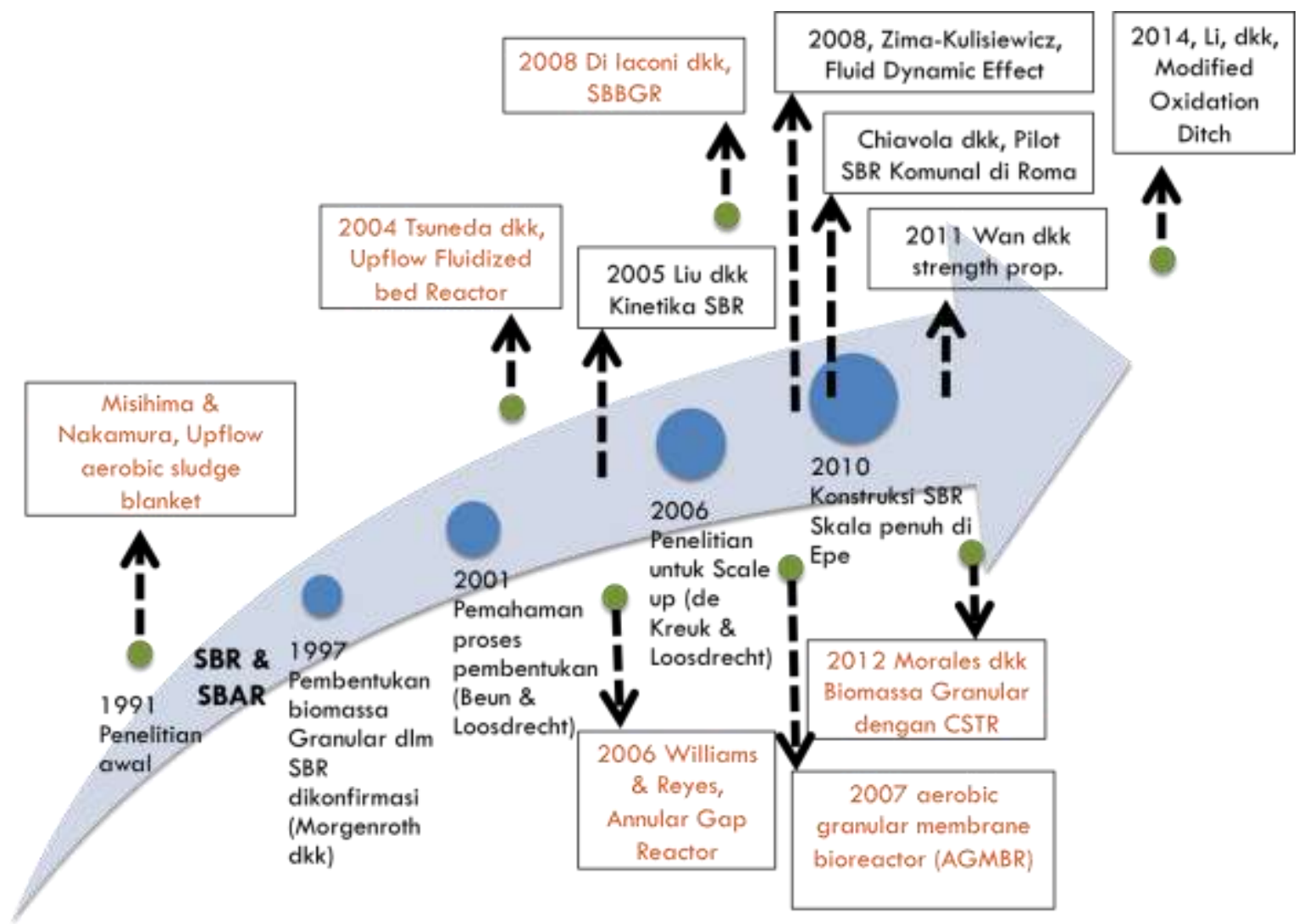

Gambar 3. Reaktor yang memanfaatkan GAS

Pada awal penelitian GAS oleh Nishima dan Nakamura (1990) menggunakan reaktor yang mirip dengan reaktor UASB, hanya saja dengan granular yang dibentuk secara aerobik. Penelitian selanjutnya yang menjadi titik tolak pengembangan GAS dengfan SBR adalah Morgenroth et. al., (1997). Di luar penelitian utama yang menggunakan reaktor SBR, maka digunakan reaktor lain dengan konfigurasi Upflow Fluidized Bed (Tsuneda, et. al., 2004), Annular Gap (Williams \& Reyes, 2006), Sequencing Batch Biofilter Granular Reactor (SBBGR) (di Iaconi et. al, 2007), Aerobic granular membrane Bioreactor (AGMBR) (Wei, Li \& Wang, 2011), dan biomassa Granular dengan Continues Stirred Tank Reactor (CSTR) (Morales, et .al, 2012).

\subsection{Reaktor Kontinu untuk Pertumbuhan GAS}

Berbeda dengan reaktor SBR, maka reaktor dengan mode kontinu relatif kurang dieksplorasi. Hal ini terutama dikarenakan reaktor dengan kontinu, terutama dengan konfigurasi Completely Mixed Tank Reaktor (CMTR) mempunyai sifat aliran terjadi secara lebih acak, sehingga pembentukan GAS menjadi tidak beraturan (Liu, 2006b). Morales et. al. (2012) menunjukkan dengan menggunakan substrat pig slurry dan model reaktor CSTR konvensional, menghasilkan GAS 
dengan SVI yang lebih jelek dibandingkan yang dihasilkan reaktor SBR. Pertumbuhan GAS untuk nitrifikasi juga dapat dipercepat dengan menumbuhkannuya terlebih dahulu di reaktor SBR (Wan et. al., 2013)

Tetapi penelitian yang lebih awal terkait dengan penggunaan reaktor kontinyu dapat dilihat pada Beun et. al. (2000) terkait dengan perbandingan pembentukan pada reaktor biofilm airlift suspension (BAS) dengan reaktor sequencing batch bubble column (SBBC) dan SBAR. Pada BAS, GAS yang terbentuk berukuran lebih kecil dengan densitas lebih rendah. Meskipun demikian, Juang et al. (2010) menunjukkan GAS yang terbentuk selama proses kontinyu dapat lebih stabil oleh karena adanya inti presipitasi yang terbentuk dari kalsium dan besi. Ganesan et. al. (2007) menunjukkan juga bahwa penggunaan inti presipitat di awal berupa karbon aktif, dapat menginduksi terbentuknya GAS pada sistem reaktor lumpur aktif.

Strategi yang terakhir untuk pembentukan GAS, misalnya dilakukan oleh Li (2014) dengan memodifikasi reaktor Oxidation Ditch (OD) untuk reaktor GAS.

\section{KESIMPULAN}

Strategi untuk perbaikan pembentukan GAS dapat dilakukan dengan memberikan inti presipitasi terlebih dahulu atau memodifikasi reaktor. Dibandingkan dengan mode operasi sequencing batch atau batch, maka reaktor kontinyu masih perlu eksplorasi lebih lanjut terkait dengan penggunaannya untuk GAS. Hal ini disebabkan penelitian-penelitian awal pada pembentukan GAS pada reaktor kontinu memberikan kualitas yang lebih rendah apabila dibandingkan dengan reaktor SBR. Eksplorasi lebih lanjut pada reaktor kontinu dengan GAS bertujuan untuk mendapatkan pemahaman yang lebih baik terkait dengan mode operasi dan reaktor kontinu.

\section{DAFTAR PUSTAKA}

Abdullah N, Ujang Z, Yahya A., 2011, Aerobic granular sludge formation for high strength agrobased wastewater treatment., Bioresource Technology 2011 Juni 102(12):6778-81

Adav, S. S., Lee, D. J., Show, K. Y., Tay, J. H., 2008, Aerobic Granular Sludge: Recent Advances, Biotechnology Advances 26 (2008), 411-423.

Bachtiar, W., \& Handajani, M., 2013, Penentuan Kondisi Optimum untuk pembentukan biogranular aerob dengan Sequencing Batch Reactor, Makalah untuk Seminar Thesis Institut Teknologi Bandung, Tidak dipublikasikan. 
Balest, L., Lopez, A., Mascolo, G., Iaconi, C. D., 2008, Removal of endocrine disrupter compounds from municipal wastewater using an aerobic granular biomass reactor, Biochemical Engineering Journal 41 (2008) 288-294

Beun, J. J., van Loosdrecht, M. C. M., Heijnen, J. J., 2000, Aerobic granulation, Water Science \& Technology Vol. 41 No. 4-5 pp 41-48

Beun, J. J., Hendriks, A., van Loosdrecht, M. C. M., 2001, N-removal in a granular sludge sequencing batch airlift reactor, Biotechnology and Bioengineering 75, 82-92

Castro-Barros, C. M., Revised by Volcke, E. I. P., 2013, Guidline for granular sludge reactor design, SANITAS Sustainable and Integrated Urban Water System Management

Chiavola, A., Sirini, P., Cecili, S., 2010, Technical and Experimental evaluation of an innovative decentralized technology for the municipal wastewater treatment in the city of Rome, Water Science \& Technology (62) Mo. 4, pp 956-962

Coma, M., Verawaty, M., Pijuan, Yuan, M., Z., Bond, P.L., 2012, Enhancing aerobic granulation for biological nutrient removal from domestic wastewater, Bioresource Technology 103 (2012) 101-108

Coma, M., Puig, S., Balaguer, M. D., Colprim, J., 2010, The role of nitrate and nitrite in a granular sludge process treating low strength wastewater, Chemical Engineering Journal 164 (1), 208-213

Ganesan, M. V., Saravanan, V., \& Sreekrishnan, T. R., 2007, Formation and Hydrodynamic Characteristic of Aerobic Granules in An Activated Sludge System, Environmental Technology Vol. 28 pp 217-224

Giesen, A., Niermans, R., and van Loos- drecht, M. C. M. (2012). Aerobic granular biomass: the new standard for domestic and industrial wastewater treatment? Water21 4, 28-30.

di Iaconi, C., Ramadori, R., Lopez, A., Passino, R., 2007, Aerobic granular Sludge Systems: The New Generation of Wastewater Treatment Technologies, Jurnal Ind. Engineering Chemical Research Vol. 46 No. 21 Hal 6661-6665

Ivanov, V., \& Tay, S. T. L., 2006, Seeds for Aerobic Microbial Granulation, Chapter in Waste Management Series 6: Biogranulation Technologies for Wastewater Treatment, Elsevier Page 213-244. 
Juang, Y. C., S.S. Adav, D. J. Lee, J. H. T., 2010, Stable aerobic granules for continuous-flow reactors: Precipitating calcium and iron salts in granular interiors, Bioresource Technology 101 (2010) 8051-8057

de Kreuk, M., 2006, Aerobic Granular Sludge Scaling up a new technology, Disertation Doctoal on Technische Universiteit Delft, Unpublished

de Kreuk, M. \& van Loosdrecht, 2006, Formation of Aerobic Granules with Domestic Sewage, Journal of Environmental Engineering, Vol. 132, No. 6, Page

Li, Z.H., Kuba, T., Kusuda, T., 2006, Aerobic Granular Sludge: a promising technology for decentralized wastewater treatment, Water, Science and Technology, Vol. 53 No 9, pp 7985

Li, J., A. Cai, M. Wang, L. Ding, Y. Ni, 2014, Aerobic granulation in a modified oxidation ditch with an adjustable volume intraclarifier, Bioresource Technology (2014)

Liu, Y. Q., Wu, W. W., Tay, J. H., Wang, J. L., 2007, Starvation is not a prerequisite for the formation of aerobic granules, Appl Microbiology Biotechnology (2007) 76:211-216

Liu, L, Wang, Z., Yao, J., Sun, X., Cai, W., 2005, Investigation on the properties and kinetics of glucose fedaerobic granular sludge, Enzyme Microb. Technol 36:307-313.

Liu, Y., 2006a, Factors affecting Aerobic granulation, Chapter in Waste Management Series 6: Biogranulation Technologies for Wastewater Treatment, Elsevier Page 99-114

Liu, Y., 2006b, Biosorption Properties of Aerobic Granules, Chapter in Waste Management Series 6: Biogranulation Technologies for Wastewater Treatment, Elsevier Page 245-244.

Loosdrecht, M. C. M., 2011, Graular Sludge from Idea to Pilot Plant, Paper on Symposium at Epe 9 May 2012

Minh, N. D., 2006, Treatment of High-Strength Organic Wastewater Using an Aerobic Granular System With Baffled Membrane Bioreactor, Thesis at Asian Institut of Technology, Unpublished

Mishima, K., and Nakamura, M., 1990, Self-Immobilization of Aerobic Activated Sludge-A Pilot Study of the Aerobic Upflow Sludge Blanket Process in Municipal Sewage Treatment, Water Science \& Technology Vol 23 No 4-6 pp 981-990 
Mo, W., \& Zhang, Q., 2013, Energy-Nutrients-water nexus: Integrated resource recovery in municipal wastewater treatment plants, Journal of Environmental Management 127 (2013), 255-267

Moghadam, B. K., 2012, Effect of Hydrodynamics on Aerobic Granulation, A thesis submitted to the Graduate Faculty of North Carolina State University, Unpublished

Morales, N., Figureroa, M., Mosquera-Corral, A., Campos, J. L., Mendez, R., 2012, Aerobic Granular-type biomass development in Continous stirred tank reactor, Separation and Purification Technology 89 (2012) 199-205

Morgenroth, E., T. Sherden, M. C. M. Van Loosdrecht, J. J. Heijnen, P. A. Wilderer, 1997, Aerobic granular sludge in a sequencing batch reactor, Water Research Vol. 31, no. 12, pp. 31913194

Muda, K., Aris, A., , M. R. Salim, Z. Ibrahim, M. C. M. van Loosdrecht, A. Ahmad, M. Z. Nawahwi, 2011, The effect of hydraulic retention time on granular sludge biomass in treating textile wastewater, Water Research, Vol. 45, No. 16, pp. 4711-4721

Ni, B. J., 2013, Formation, characterization, and Mathematical Modeling of The Aerobic Granular Sludge, Springer Theses, Berlin

Nor Anuar, A., Ujang, Z., van Loosdrecht, M.C.M., De Kreuk, M., 2006, Aerobic Granular Sludge Technology For Wastewater Treatment - An Overview, Paper on Asiawater Conference 2006

Roeleveld, P., Roorda, J., Schaafsma, M., translation from Dutch version by J. van der Heide, 2010, STOWA Report, News: The Dutch Roadmap for The WWTP of 2030, STOWA

Oakley, S. M., A. J. Gold, A. J. Oczkowski, 2010, Nitrogen control trough decentralized wastewater treatment: Procvess performance and alternative management strategies, Ecological Engineering 36 (2010) 1520-1531

Oh, J. H., 2013, Fundamental and application of aerobic granulation technology for wastewater treatment, diakses dari http://home.eng.iastate.edu/ tge/ce421521/Jin\%20Hwan\%20Oh.pdf, Desember 2013

Othman, I, A. N. Anuar, Z. Ujang, N. H. Rosmana, H. Haruna, S. Chelliapan, 2013, Livestock wastewater treatment using aerobic granular sludge, Bioresource Technology Volume 133, April 2013, Pages 630-634 
Schwarzenbeck, N., Borges, J. M., P. A. Wilderer, 2005, Treatment of dairy effluents in an aerobic granular sludge sequencing batch reactor, Appl Microbiol Biotechnol (2005) 66: 711-718

Tay, J. H., Liu, Q. S., Liu, Y., 2001, The effects of shear force on the formation, structure and metabolism of aerobic granules, Appl Microbiol Biotechnol (2001) 57:227-233

Wan, C., S. Sun, D. J. Lee, X. Liu, L. Wang, X. Yang, X. Pan, 2013, Partial nitrification using aerobic granules in continuous-flow reactor: Rapid startup, Bioresource Technology 142 (2013) 517-522

Wei, Y., G. Li, \& B. Wang, 2011, Application of Granular Sludge Membrane Bioreactor in the Treatment of Wastewater, Procedia Environmental Sciences Volume 10, Part A, 2011, Pages 108-111, 2011 3rd International Conference on Environmental Science and Information Application Technology ESIAT 2011

Wei, Y., Ji M, Li R, Qin F., 2012, Organic and nitrogen removal from landfill leachate in aerobic granular sludge sequencing batch reactors. Waste Manag. 2012 Mar;32(3):448-5

Widodo, B., Yulianto, A., Utami, S., Lupiyanto, R., 2009, Evaluation of Decentralized Communal Wastewater Treatment in Yogyakarta, 1st International Conference on Rehabilitation and Maintenance in Civil Engineering (ICRMCE), Solo March, 2009

Winkler, M.K.H., 2012, Thesis on segregation of biomass in aerobic granular sludge, Disertation Doctoal on Technische Universiteit Delft, Unpublished, Chapter 1

Jang, A., Yoon, Y. H., I S. Kim, K. S. Kim, P. L. Bishop, 2003, Characterization and evaluation of aerobic granules in sequencing batch reactor, Journal of Biotechnology 105 (2003) 71-82

Yong-Qiang Liu, Y. Q. \& Tay, J. H., 2012, The competition between flocculent sludge and aerobic granules during the long-term operation period of granular sludge sequencing batch reactor, Journal Environmental Technology 2012 pp. 1-8

Yuan, X., \& Gao, D., 2010, Effect of dissolved oxygen on nitrogen removal and process control in aerobic granular sludge reactor, Journal of Hazardous Materials 178 (2010) pp. 1041-1045

Zima-Kulisiewicz, B. E., L. Díez, L., Kowalczyk, W., Hartmann, Chr., Delgado, A., 2008, Biofluid mechanical investigations in sequencing batch reactor $(S B R)$, Chemical Engineering Science 63 (2008) 599-608 